\title{
RAFFLES' SOURCES FOR TRADITIONAL JAVANESE HISTORIOGRAPHY AND THE MACKENZIE COLLECTIONS*
}

\author{
Donald E. Weatherbee
}

\section{Introduction: The Mackenzie Collections}

Appreciations of British contributions to the scientific development of Southeast Asian Studies, specifica1ly Indonesian history, 1iterature, and cultures, begin with Raffles and Crawfurd. ${ }^{1}$ Their papers and books are milestones in nineteenth-century Orientalism. Raffles' History of Java (hereafter cited as RHJ) in particular signally influenced succeeding Dutch views of the Javanese. It remained the standard work until nearly the end of the century. ${ }^{3}$ In part this is because the work opened new ways of looking at the totality of Javanese culture and thus "brings to the fore much that is valuable in the o1d and new Javanese civilization." 4 The RHJ, however, is not so much a personal tour de force by Raffles as a synthesis of reports and materials prepared and assembled by others.

Raffles, in introducing the "history" component of the RHJ (Vol. 2, Chapters 10 and 11), claimed that his sources were based on "native writings" provided him by the Panembahan of Sumenep, the Secretary of the Pangeran Adipati of Surakarta, and the late Kyahi Adipati of Demak [Sura Adimenggala].5 According to Raffles, Sura Adimenggala's abstract

*The author wishes to express his gratitude to the Librarian and staff of the India Office Library for their help and cooperation. Particular thanks are due to Dr. F. J. Bingle and Miss Jane Bebbington for their assistance while the author was working his way through the Mackenzie Collections. The author's research, 1970-71, was made possible by support for a sabbatical year from the University of South Carolina and the Earhart Foundation.

"One should not forget," writes John Bastin, "that the real beginnings of Indonesian Historiography are to be found not so much in the work of the early Orientalists at Leyden or in the writings of Valentijn as in the massive histories which were published by the British scholars Marsden, Raffles, and Crawfurd, at a time when Indonesian studies attracted little attention in the Netherlands." "English Sources for the Modern Period of Indonesian History," in Soedjatmoko et al., eds., An Introduction to Indonesian Historiography (Ithaca: Cornell University Press, 1965), p. 252.

${ }^{2}$ Thomas Stamford Raffles, The History of Java (1817; reprint ed. [with introduction by J. S. Bastin; 2 vols.] Kuala Lumpur, New York: Oxford University Press, 1965).

${ }^{3 B a s t i n, ~ " E n g l i s h ~ S o u r c e s, " ~ p . ~ 262 ; ~ J . ~ G . ~ d e ~ C a s p a r i s, ~ " H i s t o r i c a l ~ W r i t i n g ~ o n ~}$ Indonesia (Early Period)," in D. G. E. Hall, ed., Historians of South East Asia (London: Oxford University Press, 1961), p. 122.

${ }^{4} \mathrm{H}$. J. de Graaf, "Aspects of Dutch Historical Writings on Colonial Activities in South East Asia with Special Reference to the Indigenous Peoples during the Sixteenth and Seventeenth Centuries," in Hall, Historians of South East Asia, p. 218.

${ }^{5} \mathrm{RHJ}, 2, \mathrm{p} .64$. 
provided the principal framework for his account, being the most continuous of the "native accounts" available. 6 Bastin has remarked, "No attempt, so far as I know, has yet been made to analyze in detail Raffles' use of Javanese and Malay sources in his History."7 Raffles did note that, "In the course of the narrative, a Dutch abstract of the native history, by $\mathrm{Mr}$. Middelkoop has occasionally been consulted,"8 and the first paragraph of Chapter 10 has a note referring to "Midde1koop's Collection."9 As it turns out, however, large sections of this chapter and the next are borrowed by unattributed close paraphrase or direct quotation, without indication of quotation, from J. A. van Middelkoop's manuscript History of Java from the extent of this borrowing it can be concluded that Middelkoop's manuscript (hereafter cited as MMS) rather than the old Adipati's contribution served as Raffles' basic framework. The English translation of the MMS can be found in the Manuscript Collections of Lieutenant Colonel Colin Mackenzie now housed in the India office Library, London. 10

Although, unlike his better-known contemporaries, Mackenzie left no printed monument to his own scholarly endeavors during the British interregnum on Java, his European and Javanese language manuscript collections are invaluable. Not only do they provide documentation of Java's political and economic organization during the English period, 11 but they also reflect their author's broader purpose of acquiring "materials for a complete view of the geography, statistics, and history ancient and modern of Java, and the Dutch dependencies in the Eastern islands."12 Mackenzie's antiquarian and historical investigations on Java were carried out on commission of Lord Minto, GovernorGeneral of India. Raffles, himself, acknowledged Mackenzie's contributions to the RHJ.13

Mackenzie's task on Java was, in a sense, a continuation of scholarly pursuits that had, since 1796 , produced a massive collection of South Indian historical and linguistic materials. ${ }^{14}$ He had served

${ }^{6}$ Ibid. 7J. S. Bastin, Introduction to RHJ, n. 11.

${ }_{\mathrm{RHJ}}, 2$, p. 64. 9Ibid., p. 65. 10Mackenzie, Private Collection, 8.

${ }^{11 B a s t i n, ~ " E n g 1 i s h ~ S o u r c e s, " ~ p . ~ 260 . ~ M a c k e n z i e ~ w a s ~ P r e s i d e n t ~ o f ~ R a f f l e s ' ~ c o m-~}$ mission to investigate 1 and tenure and copies of the commission's materials are in the collections. Bastin mined them for his studies of Raffles' administration: John Bastin, Raffles' Ideas on the Land Rent System in Java, Verhandelingen van het Koninklijk Instituut voor Taal-, Land-en Volkenkunde [henceforth VKI], 14 (The Hague: Nijhoff, 1954); John Bastin, The Native Policies of Sir Stamford Raffles in Java and Sumatra (Oxford: Clarendon Press, 1957).

12"Biographical Sketch of the Literary Career of the Late Colonel Colin Mackenzie . . contained in a letter addressed to him to the Right Hon. Sir Alexander Johnstone, V.P.R.A.S., etc. etc. "Joumal of the Royal Asiatic Society [henceforth JRAS], 1 (1834), p. 346.

${ }^{13}$ For a discussion of this see John Bastin, Introduction to RHJ.

${ }^{14} \mathrm{H} . \mathrm{H}$. Wilson, The Mackenzie Collection: A Descriptive Catalogue of the Oriental Manuscripts, and other Articles Illustrative of the Literature, History \& Statistics and Antiquities of the South of India Collected by the Late Lieutenant Colonel Colin Mackenzie, Surveyor General of India (Calcutta: Asiatic Press, 1828; 2nd ed., Madras: Oriental Manuscripts Library, 1882). 
there as engineer and surveyor. In 1811, he was appointed Chief Engineer to the British expedition against Java.15 On a reconnaissance mission, he was, in fact, the first senior British officer to set foot on Java. Mackenzie remained on Java for two years, July 1811-July 1813. His military duties included serving as senior engineer at the siege and reduction of the Yogyakarta kraton in June 1812. Finishing his work on the tenure commission at the end of February 1813, Macken$z$ ie was relieved as chief engineer in July 1813 and returned to Calcutta. At the "urgent request" of the government he remained in Bengal to arrange his collections and prepare his reports, the first of which was completed in November 1813.16 His military report and journal were transmitted in December 1813,17 and a final report with a register of documents was submitted in February 1815.18 In that year, Mackenzie was appointed Surveyor-General of India, a position held until his death in 1821 .

According to Mackenzie, his "historical investigations" on Java were "effected under limitations of time and means required by local circumstances; but under a liberal degree of encouragement and protection both from the local government there, and from two successive governor-generals of British India, which heightens the contrast in other cases and without any expenses to Govt. on that account."19 As far as "History and Antiquities" are concerned, the results included 35 volumes of manuscripts in Dutch, some being translations from the Javanese, and 177 "sections rather than volumes of paper MSS written in the characters of Java and of the Malay; but a11 in the Javanese language."zo Mackenzie's sources were varied. He wrote of the Javanese manuscripts:

Some were saved from the wreck of the Sultan's library at the storm of the Craten [kraton] of Djocjacarta, by permission of the prize agents and the concurrence indeed of all the military present --others were purchased and collected on the tour through that island: some were presented by Dutch colonists and regents, and others are transcripts by Javanese writers employed by Colonel Mackenzie to copy them from the originals in the hands of regents, and with their permission. ${ }^{21}$

15For Mackenzie's biography, see W. C. Mackenzie, Colonel Colin Mackenzie, First Surveyor-General of India (Edinburgh: W. \& R. Chambers, 1952). His years in Java are covered on pp. 101-70. See al so Dictionary of National Biography; R. H. Phillimore, Historical Records of the Survey of India (Dehra Dun [U.P.], 1945), sv Mackenzie.

16"A General View of the Results of Investigations into Geography, History, Antiquities, and Literature of the Island of Java, by Lieutenant Colonel C. Mackenzie in the Years 1811-12-13," dated Fort William, November 10, 1813. JRAS, 1 (1834), pp. 353-60.

17"Report and Journal of Lieutenant Colonel C. Mackenzie's Proceedings on the Is land of Java from 1st October 1811 to 7 th June 1813 transmitted to the Commander in Chief at Ft. St. George and Continuation afterwards to the 19 th July 1813 communicated with a copy of the former to the Government at Ft. William of [sic] 14 th December 1813," Mackenzie Private Collection, 14, pt. 15.

${ }^{18}$ East India Military Calendar, 3 (London, 1826), p. 321.

19 Mackenzie, "General View." 20Ibid. 21 Ibid. 
The Mackenzie collectiuns are particularly valuable as illustrative of the literary and historical tradition in the Yogyakarta court, especially work done under the patronage of the Crown Prince and later Sultan Amengkubuwana II (1792-1812).22 They are also $\mathrm{rich}$ in materials from Semarang, where F. von Wickelmann acted as agent for Mackenzie-obtaining manuscripts, having them copied, and arranging when necessary for their translation. At the time of the British conquest, Winckelmann was Brigadier and Commandant at Semarang. With Mackenzie's sponsorship, he was appointed Inspector of Forests (April 1812) and member of the Commission for Land Purchase (August 1812), becoming its superintendent in February 1814.23 Through Winckelmann, Mackenzie retained the services of J. G. Vincent who accomplished many of Mackenzie's translations from Javanese to Dutch. Vincent had been on Java since 1772 , as a clerk and translator in Bantam and Surakarta before settling in Semarang. 24 With the assistance of native speakers he tried to meet the demands of Mackenzie, ${ }^{25}$ who became increasingly impatient with the slow pace of translation. Although Winckelmann had no high opinion of Vincent, he defended him to Mackenzie, writing to him in February 1812, "Truly, my dear Colonel, this very weak man now gives himself all possible pain to furnish you with a good and faithful translation."26 The problem of translation plagued Mackenzie. He noted that:

The difficulty of procuring any of the colonists capable of acting as interpreters was considerable, from the rarity of these necessary qualifications, and from a repugnance to travelling and fatigue, arising from indolence, and from habits widely dissimilar to ours . . Javanese in its several dialects had been little studied by the European colonists of Java; these few were in the service of the government; and there were but few on the island capable of rendering a letter from the Javanese into Dutch. ${ }^{27}$

Through his Semarang connections Mackenzie came into contact with one of the more interesting Javanese figures of the British interregnum, Kyahi Adipati Sura Adimenggala (Bustaman), 28 who became a confidant of Raffles and was acknowledged by $h i m$ as an important informant for the RHJ.29 Through his Dutch friends in Semarang, the old Adipati sought

${ }^{22}$ For the milieu see Merle C. Ricklefs, "On the Authorship of Leiden Cod. Or. 2191, Babad Mangkubumi," Bijdragen tot de taal-, land-en volkenkunde (henceforth $B K I), 127$ (1971), pp. 264-73.

${ }^{23} \mathrm{~F}$. de Haan, "Personaiia der periode van het Engelsch bestuur over Java 1811$1816, " B K I, 92$ (1935). A portion of the Winckelmann-Mackenzie correspondence is in the Private Collection, 74.

${ }^{24}$ Johannes Gilbertus Vincent is not mentioned by De Haan, "Personalia." Personal details about Vincent's career are given in a letter from him to Winckelmann, January 7, 1812 (Private Collection, 74, pt. 1) and a letter from Vincent to Mackenzie, October 10, 1812 (Private Collection, 74, pt. 9).

${ }^{25}$ In a letter to Winckelmann (?), Vincent laments that even with the assistance of Ki Dipati Raden Gonda and three other knowledgeable informants the meaning of a difficult text continues to elude him. (Private Collection, 74, pt. 2).

${ }^{26}$ Private Collection, 74, pt. 25. 27Mackenzie, "General View."

${ }^{28}$ De Haan, "Personalia"; P. H. van der Kemp, Oost-Indie's herstel in 1816 (The Hague: $M$. Nijhoff, 1911), pp. 249-51.

29RHJ, 2, p. 62. 
to ingratiate himself with Mackenzie. His specific request was that he be made Regent of Demak, if the territorial changes made by Daendels were corrected, or, failing that, to have the English regime remove the Regent of Semarang and put him in that function (which in fact occurred).30 Winckelmann represented Sura Adimenggala to Mackenzie as a "brave old man" beset on all sides by his political enemies, the "object o clandestine persecution."31 Vincent wrote a letter on behalf of Sura Adimenggala, warning that the contents should be destroyed after reading lest "the supplicant's request comes to the ears of those that have sought his misfortunes."32 Mackenzie favorably recommended him to Hugh Hope, Civil Commissioner for East Java.,33 At least five of the Javanese manuscripts in the Private Collection can be attributed to Sura Adimenggala, who presented them as gifts to Mackenzie. ${ }^{34}$

In general Mackenzie found that "The regents and their dependents were, though at first shy, ultimately cordially assisting to the objects of investigation."35 Mackenzie traveled extensively on Java in the course of his inquiries.36 In February 1812 he passed down the Solo River from Surakarta to Surabaya. Detained in Surabaya while awaiting preparation of official reports, he journeyed in March 1812 to Madura spending time at the court of the Sultan at Bangkalan (Cakradiningrat I), as well as passing four days traveling from one end of the island to the other and becoming acquainted with the Panembahan Sumĕnĕp 37 (Natakusuma, an important informant for the RHJ) and Pangeran Paměkassan.38 On his return to Surabaya, he made a three-day

30Vincent to Winckelmann (?), Private Colzection, 74, pt. 5.

${ }^{31}$ Ibid., pt. 14. $\quad 32$ Ibid., pt. 5. $\quad 33$ Ibid., pt. 16.

${ }^{34}$ IOL Jav 1, Niti Praja; IOL Jav 2, Sewaka; IOL Jav, Nagara Krama; IOL Jav 18, Paniti Sastra; and IOL Jav 67, Serrat Pakĕm Watu Gunung. The first three texts have identical colophons dating them at Sermawis (Semarang) 15 Rabingulawal 1739 A.J. (in Javanese numerals) or March 29, 1812 A.D. Winckelmann wrote to Mackenzie in Surabaya on March 31, 1812, that the Ki Dipati had provided the three books on March 30, and that the Niti Sastra would follow in a few days. The Paniti Sastra itself is only dated 1812. On August 15, 1812, Vincent acknowledged he had received the Niti Sastra for translation. Mackenzie became vexed with the slowness of Vincent's work, but by January 25, 1812, Winckelmann reported it finished. As is the case with so many other of Vincent's translations from Javanese to the Dutch it did not become part of the collection. Rather there is an English translation Mackenzie, 1822 Colzection, 26, pt. 2) accomplished in March 1820. See C. 0. Blagden, Catalogue of Manuscripts in European Languages Belonging to the Library of the India Office, vol. 1: The Mackenzie Collections, part 1: The 1822 Collection and the Private Collection (London: Oxford University Press, 1916), p. 25 (hereafter cited as Blagden, Catalogue).

35Mackenzie, "General View."

36Mackenzie, "Report and Journal," details his travels.

37IOL Jav 13, a Sajarah Sumĕnĕp is noted by Mackenzie: "Javanese Historical MS received from the Panambahan's Son at Samanap in Madura March 1812." IOL Jav 25, a Bharata Yuddha in 0ld Javanese in Balinese script with an interlinear modern Javanese "translation" has an autograph note by "CMck" that "This MS was sent me by the son of the Panambehan of Sumanep vide letter from Capt. Garnham, September, 1812" [Robert C. Garnham, Resident at Sumĕnĕp].

${ }^{38} \mathrm{IOL}$ Jav 16, a Serrat Roma, was described by Mackenzie as "History of Java in the Madurese Language and Javanese Characters received from the Pangerang of Pamekassan, March, 1812." 
excursion to the Brantas delta and the district of Japan (Majakerta) returning by water from Wirasaba. On Apri1 21, 1812, he left Surabaya via the Post Road through Gresik, 39 Tuban, Lasem,40 Rembang, and Juwana. From Juwana he went by river to Pati and thence to Cenkal Sewu, Japara, Kudus, 41 arriving at Semarang on May 5. He stayed in Semarang on commission business until, in June, he accompanied Raffles and Gillespie on the Central Javanese expedition. Mackenzie did not play a political role in the events surrounding the reduction of the Yogya kraton, and unlike the other senior English officials, does not figure in the Javanese accounts of this period. He left Yogyakarta with the last detachment of Company troops returning to Semarang on July 18 , 1812. After a month, he returned to Batavia, where he continued to be occupied with his enquiries and duties as President of Raffles' Commission. Mackenzie received manuscripts in copies and originals right up to the last moment of his stay. Some of the materials contained in the collection, however, date from after his departure and were sent to him in India.

At Mackenzie's death the manuscripts that had been bought or copied at government expense were transferred to the East India Company and make up what is known as the 1822 Collection. The largest part of the materials from Java, those acquired on his own account, were purchased from the estate and make up the Private collection. The 1822 Collection and the European language manuscripts of the Private Collection are partially described in Blagden's 1915 catalog.42 The Javanese language manuscripts have been recently catalogued by Ricklefs and Voorhoeve, 43 but some manuscripts from Mackenzie's Java collections remain uncatalogued in the so-called Miscellaneous Collection.

In attempting to assess the importance of the Mackenzie collections for Indonesian studies, one is immediately struck by its uneven diversity. Although Mackenzie reported that his researches had "produced an accession of knowledge and lights that had been by no means hoped for, even in the most sanguine expectations, 144 it must be noted that he and his contemporaries used the term "history" to cover a wide variety of disparate materials and information.45 In the RHJ, for

${ }^{39} \mathrm{IOL}$ Jav $12 . \mathrm{B}$, is a history of Sunan Giri received from the Adipati of Gresik in April 1812 . 1812.

${ }^{40}$ IOL Jav 29, is a Babad Jawi presented by the Adipati of Lasem at Kudus, May 5,

41IOL Jav 17, was described by Mackenzie as a "History of Java, the origina1 communicated by the Adipati of Coodus and copied at Semarang, July, 1812." It actually is two texts, a Pañji Angreni and an Angling Darma.

42For examples of items Blagden was unable to identify, see Blagden, Catalogue, pp. 37,145 .

43M. C. Ricklefs and P. Voorhoeve, Indonesian Manuscripts in Great Britain: A Catalogue of Manuscripts in Indonesian Languages in British Public Collections (London: Oxford University Press, 1977), pp. 58-73. The entries for the Mackenzie Javanese manuscripts are based on the present author's "Inventory of the Javanese Paper Manuscripts in the Mackenzie Collection, India Office Library" [typescript, 1972].

44Mackenzie, "General View."

45'Marsden, Raffles, and Crawfurd all used the title 'History' in something like the original Greek sense of inquiry; it meant to them 'a comprehensive view' (a 
example, the history of Java, in the modern sense, is contained in Vol. 2, Chapters 10 and 11. Already in 1896 , Brandes had remarked the importance of the British collections in general for Javanese history, in particular because of their relative antiquity when compared to later Dutch collections.46 A simple examination of the catalogs cannot convey the value of the collections. This must await careful study of individual items. For the Javanese language chronicles, this has only just begun with Ricklefs' pub1ication of the Babad ing Sangkala (IOL Jav 36 [B]), the oldest extant original copy of a traditional Javanese history (1738 A.D.).47 Among the Dutch language manuscripts is a historical text which has been given attention in another copy. This text, together with the singular English language translation of the MMS, illuminates the historical tradition of the RHJ.

The Engelhard Šrat Kanda, Middelkoop's "History of Java," and the RHJ

Reporting on his acquisitions, Mackenzie listed among "the more remarkable" Dutch language manuscripts "a complete history of Java, in three quarto volumes, translated into Dutch, giving its history from the first supposed colonization to the year 1807; the original apparently written by a native. This is now nearly translated into English."48 This description corresponds to Mackenzie, Private Colzection, 23, Vols. 1, 2, and 3 to p. 346 (Blagden, Catalogue, pp. 115-17), headed: Translaat van een Javaansch Beschryving van de oorsprong der eerste Bewoonders van dit Ey Zand Java. In his annotation Blagden mere$1 y$ noted that there were many Javanese recensions of the history of Java, with general reference to Vreede's and Juynbol1's catalogues of the Leiden collections. It is now possible to be more specific. The content of these volumes is identical to the former Bataviaasch Genootschap's Manuscript 540 , the so-called "Engelhard Serrat Kanda."

In 1807 A.D., Nicolaas Engelhard (1761-1831), then Governor of Java's Northeast Coast at Semarang, had translated into Dutch a traditional Javanese historical text. Its provenance was probably the court of the Semarang bupati.49 The only known manuscript attracted no notice until it was taken up into the Bataviaasch Genootschap's collection (K.B.G. MS 540). It was first described by Brandes as "a Dutch translation, in four volumes, with continuous pagination from page 1 to page 1439 inclusive, of a babad in which the history of Java is related up to the death of Mangkurat II in A.J. $1626=$ A.D. 1702."50 The

phrase dear to Crawfurd) or a general descriptive account of a country or region." B. Harrison, "English Historians of 'the Indian Archipelago': Crawfurd and St. John," in Hall, ed., Historians of Southeast Asia, p. 246.

${ }^{46} \mathrm{~J}$. L. A. Brandes, Pararaton (Ken Arok) of het Boek der Koningen van Tumope 2 en Majapahit, 2nd ed., Verhandelingen van het Bataviaasch Genootschap van Kunsten en Wetenschappen [henceforth $V B G$ ], 62 (1920), p. 204, n. 4.

47M. C. Ricklefs, Modern Javanese Historical Tradition: A Study of an Original Kartasura Chronicle and Related Materials (London: School of Oriental and African Studies, 1978).

48Mackenzie, "General View."

${ }^{49}$ De Graaf, "Aspects of Dutch Historical Writings," p. 217.

${ }^{50}$ Notulen van het Bataviaasch Genootschap [henceforth NBG], 42 (1904), p. 129. 
text was further divided into 56 sections or chapters. The divisions which seem, at times, to be rather arbitrary in terms of rational organization of the subject matter may reflect the organization of a Javanese language original in macapat verse. Brandes deemed the babad translation to be very important, and suggested that there were some remarkable parallels between this text and the contents of the great Serrat Kanda (Jav MS K.B.G. 7). He concluded that for the pre-Majapait history, at least, a close relationship must have existed between the two. Brandes suggested that a critical study of the babad translation would significantly add to the knowledge of traditional Javanese historiography.51 Although Brandes had underlined its importance, it was not until half a century later that the manuscript was seriously studied. Dr. H. J. de Graaf called it the "Engelhard Serat Kanda" (hereafter cited as ESK) and profitably exploited it as a major primary source for his pioneering studies of Moslem Mataram's early rulers.52 De Graaf, describing the ESK as "valuable" and "remarkable," argued that for the period of the founding of Mataram its readings seemed to be older and more original than those of the better known Babad Tanah Jawi tradition (hereafter cited as BTJ).53

The present author initially established the identity between Mackenzie, Private Collection, 23 and K.B.G. MS 540 by comparing the Mackenzie copy of the ESK to a typescript of extracts from the Jakarta text.54 Mackenzie's ESK runs 1,087 pages numbered consecutively within the three bound volumes which are divided into afdeelingen (sections or chapters). Both manuscripts are dated in an identical fashion containing the same error (?) and omission. The date is expressed within the framework of the myth of Aji Saka, the traditional Javanese culture bearer.

At that time he began to invent the calendar commencing with the year one. This chronology has descended from generation to generation of the Javanese people right down to the present day on which this account is translated: being Tuesday, the first of the lunar month Rĕjĕb, in the year Jimawal, or the [ ]55 February, 1807; 1733 years having elapsed. These four numbers were expressed in his time and language by the following words: tělu guna ning pandita siji. Tĕlu means three; guna ning, three a1so; pandita, seven; and siji, one. The four words express the date of the current Javanese year, 1733. [Translated from the Dutch.] 56

51 Ibid., p. 133.

52 H. J. de Graaf, De Regeering van Paněmbahan Sénapati Ingalaga, VKI, 13 (1954); De Regeering van Sultan Agung, 1613-1645, en die van zijn voorganger Panembahan Sédaing-Krapjak, VKI, 23 (1958); De Regeering van Sunan Mangkurat I, vo1. 1, VKI, 33 (1961); vol. 2, VKI, 39 (1962). De Graaf's work has recently been summarized in English in Th. G. Th. Pigeaud and H. J. de Graaf, Islamic States in Java, 1500-1700, $V K I, 70$ (1976).

${ }^{53}$ De Graaf, Sénapati, p. 4. Citations of the BTJ are to the W. L. Olthoff translation of the Meinsma prose BTJ (The Hague: Nijhoff, 1941).

${ }^{54} \mathrm{Dr}$. de Graaf very courteously made the typescript available to the author at the Koninklijk Instituut voor Taal-, Land- en Volkenkunde in 1963.

${ }^{55}$ Both copies of the ESK have a blank space in the text for the day of the month in the Gregorian calendar.

56Mackenzie, ESK, vol. 1, pp. 4-5, cited as well from K.B.G. MS 540 by Brandes, 
Brandes had already noted the lack of congruity between the Javanese date and the Gregorian date. 1 Rĕjěb, Jimawal, 1733 A.J. was September 15, 1806 A.D. He suggested that it probably should read 1 Dulkijah which would be February 10,1807 A.D.57 Since throughout the text the year $1807 \mathrm{~A} . \mathrm{D}$. is used to date precedent events, it is likely that the error is in the Javanese date. This is the date of the translation from the supposed Javanese original. Although there is no direct indication of the date of the composition of the Javanese original, a prophecy that occurs in the text gives an indirect suggestion of a terminus a quo. The last Majapait king, Angka Wijaya, foretells the future of the descendents of Bondan Kajawan: "In my seventh generation and from then on the descendents shall have sovereignty over Java, keeping their court at Mataram, Kartasura, and finally Surakarta in Pajang" (ESK, 1, p. 214). The kraton was established at Surakarta in 1743 A.D. An earlier prophecy (ESK, 1, pp. 81-82) located the royal kratons at Majapait, Demak, thereafter to Pajang, Mataram, and finally to Kartasura. Both extant copies of the ESK end at exactly the same point--the death of Mangkurat II in 1702-3 A.D.:

Nog verscheijdene andere heijlsaame vermaaningen en lessen had de vorst aan zijn zoon de Kroon Prins dagelijks, voor zijn dood gegeeven. En niet lang daarna wierd de vorst door de wille des aller Hoogsten God--Ziek, en op vrijdag avond is zijn hoogheid de soesoehoenan Amang Coerat de 2 de uijt dit tijdelijke ontbonden, en na de eeuwigheid overgegaan, dat geweest is in het Javaansche Jaar 1626; zederd welke tijd tot in Hollandsch Jaar 1807, is geleeden 108

Jaaren lang. [1703 A.D.] (ESK, 3, p. 346)

Immediately following the ESK in Private colzection, 23, 3, pp. 349-53, is a "Register van de Stigtingen, Verplaatsingen, en Vernietiging van de Vorstelijke Hooven van die Eijland Java." The dates given are those of the ESK but continue to the reign of Pakubuwana II, who died in 1749 A.D.

There is no record in the Mackenzie collections giving details of the acquisition of the ESK manuscript. Extant circumstantial evidence, however, connects it to the Semarang-based translator J. G. Vincent. In a letter to Winckelmann of January 7,1812 , Vincent responded to a question raised by Mackenzie about the meaning of the word "Piramiden," the "denkteekens" erected by Aji Saka in his journeys in Java.58 The locutions are strikingly similar to the working of the ESK: "Hij [Aji Saka] bouwde Piramiden op tot gendenksteeken in eenige der Landschappen, en deed Beelden uithouwen, in verschillende gedaanten, gestalte en figuren van Steenen..." (ESK, 1, p. 9). Winckelmann, several days later, conveyed to Mackenzie, Vincent's comments "about the word pyramid occurring in the manuscript."59 The manuscript referred to is probably the ESK. Later, in a letter to Mackenzie, Vincent, discoursing on Javanese language and literature, remarks: "Deeze verhevene woord en zinryke taal schijnt zonder alle teegen spreeking haaren oorsprong--ryjkdom en uitbeelding werkelyk verschuldigdte zyn an de eersten Ontdekkers en Colonisten die volgen de geschiedenis van Java,

$N B G, 1904$, p. 130. A11 further references to the ESK will be to the Mackenzie manuscript.

57NBG, 1904, p. 130. 58Mackenzie, Private Colzection, 74, pt. 1.

59 Ibid., pt. 12. 
door mij uit de oude en beste Javansche manuscripten vertaalde en an U Ed. Gestr. overgelaaten, van de kust van het vasteland Indiers overkwamen."60 This is followed by a summary of the first part of the ESK. If the suggestion is correct, that Mackenzie received his ESK in late 1811, through Winckelmann from Vincent, who claimed to be the translator of it "from the old and best Javanese manuscripts," what can be said then of the origin of the other copy of the ESK? It must be from the same translator-compiler's hand. The texts are the same. If Vincent was responsible for the one, he was responsible for the other.61

The English language translation that Mackenzie mentioned as being near completion can also be found in the India Office Library manuscripts. The first volume of the English version is Mackenzie, 1822 Collection, 22: "Translation of an Account in the Javanese Language of the Origin of the first Inhabitants and of the History of the Island of Java" (Blagden, Catalogue, p. 17).62 Blagden suggested that the translation was fragmentary, but, on further investigation, the present author has determined that the English translation in its entirety exists; the two volumes completing it being among the uncatalogued manuscripts of the Miscellaneous Colzection.

The existence of the ESK demonstrates again that, despite the significance of the RHJ in the intellectual history of Indonesian studies, it was not in the British interregnum that interest in traditional Javanese history was first manifested by European officials and scholars. Already, in the mid-eighteenth century, Gordijn had translated a Sejarah Raja Jawa which, with notes by J. van Iperen, was published in the Verhandelingen of the Bataviaasch Genootschap.63 This Dutch translation of a babad was rendered into English for Mackenzie in 1813.64 Other Dutch officials who had interested themselves in Javanese history and antiquities before the English "inspiration" are also represented by translation in Mackenzie's Private Collection.65

This raises anew the question of the possible sources of the historical data in the RHJ. Brandes had already noted Raffles' "borrowing"

${ }^{60}$ Ibid., pt. 9.

${ }^{61}$ The sketchy details of Vincent's career as given in correspondence relating to his work for Mackenzie are that in $1772-73$ he worked in Bantam as a Secretary in the Zoldij Kantoor. Then he went into private service. Sometime around 1779-80 he had settled on the Northeast coast of Java (Semarang). Part of the following years he had spent at the court of Solo where because of his "public function" he had had the opportunity to become skilled in Javanese. It is possible that his "public duties" were connected to the establishment of the last Governor and Director of Java's Northeast Coast, N. Engelhard (1801-8), to whom the commissioning of the translation of the ESK is attributed.

62Blagden, Catalogue, p. 18, suggests that the Javanese language original might be found in the Mackenzie Javanese manuscripts. This is not the case.

63VBG, 1 (1779), pp. 134-72; 2 (1780), pp. 262-88; and 3 (1781), pp. 185-202.

${ }^{64}$ Private Collection, 9; Private Collection, 68.

65Private Collection, 16, pt. 1: "History of Java Translated by A. Brand for C. Mackenzie, Oct 1814," p. 1, "Copy of an Historical Account of the Island of Great Java by François Van Boeckholt with some additions and appendix augmented by Johannes Ekenholm" (Blagden, Catalogue, p. 100). The Dutch original of Private Collection, 16 is Private Collection, 28, pt. 1 . 
and asked whether or not the ESK might have served him as a source as well. "In my opinion," he wrote, "it would certainly repay the effort to investigate more closely the relationship between it [ESK] and Raffles' text because it can be stated that in both material appears that cannot be found elsewhere"66 (italics added). In fact, the MMS--J. A. van Middelkoop's manuscript "History of Java"--contains materials in a detail and language that connect it, rather than the ESK to Raffles' "History."

The extant version of the MMS, in English translation, is Mackenzie, Private Colzection, 8, titled "History of the Island of Java from the Period of its first Population, together with Seven Memoirs of the most remarkable Trees, Plants, Quadrupeds, Birds, Fishes, Serpents and Snakes which are found in the Forests, Rivers and Lakes of this Island." On a separate sheet pasted into the bound volume is the dedication: "Dedicated to His Excellency Thomas Stamford Raffles Esqre Lieutenant Governor of the Island of Java and Its Dependencies." In an autograph note, Mackenzie described the manuscript as a "Collection of Javanese Historical Materials, Vol. I." That this is the MMS is proved by the presence in the Mackenzie Collections of a fragment of the Dutch original, "Extracted from Mr. Middelkoop's History."67 A textual comparison of the one attributed extract from the MMS in Raffles (2, pp. 65-66) with the Private collection, 8, pp. 3-6, confirms that the latter is indeed the MMS.

Jacob Albert van Middelkoop arrived on Java in 1793. When Enge1hard was Governor of Java's East Coast at Semarang, Middelkoop was at Semarang as an onderkoopman. He went on to become resident at Tegal and then Civil Commissioner of the extreme East of Java (Oosthoek). For a short time under the English, he was Civil Commissioner at Semarang. Later Dutch appraisals of Middelkoop, which are unflattering, $6 \mathbf{6}$ accused him of unsavory dealings with Daendels and currency speculation during the English occupation of Java. His personality was described as unpleasant, selfish, and devious. It is not clear when or under what motive Middelkoop compiled his "History." He had, however, a1ready sent it to Raffles by the end of 1812 since, in a letter to Van Boeckholtz, December 9, 1812 (from Semarang?), Middelkoop stated his satisfaction that Raffles had received the pieces he had sent concerning the history of Java.69 Winckelmann who was acquainted with Middelkoop, in January 25, 1813, informed Mackenzie that he was trying to get copies of Middelkoop's papers. ${ }^{70}$ A few days later he was able to tell Mackenzie that he was sending part of Middelkoop's history of Java.71 This would explain the fact that Mackenzie labeled the manuscript Volume $I$, and that it breaks off abruptly in the middle of a sentence. The English language manuscript runs 280 pages and is organized in 558 numbered paragraphs through page 214 from where it continues without further internal division to the end.

Middelkoop introduced his work by saying: "I have undertaken to put down in writing what I have been able to collect through my re-

\footnotetext{
${ }^{66}{ }_{N B G}, 1904$, p. $133 . \quad 67$ private Collection, 28, pt. 9.

68De Haan, "Personalia"; van der Kemp, Oost-Indie's Herstel.

69De Haan, "Personalia." 70Private Collection, 74, pt. 23.

71 Ibid., pt. 25.
} 
searches, during a long residence on Java, as well as from old manuscripts, and from the relations of ingenious and creditable persons whose knowledge was founded upon tradition, and for the most part derived from the ancient Pantongs or Wayangs of which the Javanese his tory is composed" (MMS, p. 1). Middelkoop's history is not a translation of one text, since editorial judgments and asides intrude. On the other hand, through the period of the foundation of Mataram the text reflects a continuous tradition paralleling that of the ESK. It is understandable that Brandes might have wondered whether Raffles had the ESK at his disposal. The actual relationship between the two will be discussed below. The legendary and traditional parts of the MMS were certainly drawn from Javanese sources, but the narrative from the middle of the seventeenth century A.D. forward more and more assumes a Dutch vantage point with the important dates being relevant to the VOC's war and diplomacy in Java as opposed to the internal history of the Javanese courts themselves.

Summary and Comparison--ESK, MMS, and RHJ

Raffles' dependence on Middelkoop's "History" and the common historical tradition of the latter and the ESK can best be illustrated by a brief comparison of the three texts. Our survey will be limited to the period up to Senapati and the founding of Mataram since: (1) De Graaf has already provided a summary of ESK from that period through the seventeenth century A.D., and (2) the MMS becomes more a Dutch historical chronicle after the founding of Mataram. A close study of the complete texts of both manuscripts, however, as De Graaf has certainly proved, would, of course, be rewarding. We will epitomize here the ESK, noting the differences of the MMS and RHJ, and the essential identity between the latter two.

ESK (pp. 1-10).72 History of Aji Saka the first discoverer of Java and ancestor of the first colonists from Gujrat. Aji Saka was the Javanese culture bearer inventing the calendars, the alphabet, and raising commemorative monuments and images throughout the island.

RHJ, 2, Chapter 10, pp. 65-66, begins with an account of the first inhabitants of Java, who were exiles from Egypt and had voyaged from the Laut Merah (Red Sea). This is based on MMS, pp. 3-6. Middelkoop claimed to have been told the story of the Red Sea people by Mangong, the 1ate bupati of Sumenĕp, who was killed in August 1811 during the landing of British troops. Both Raffles and Middelkoop continue with versions of the Aji Saka myth. Although RHJ, 2, pp. 66-69, shows evidence of having consulted MMS, pp. 6-11, Raffles' tales are said to be based on examples of pralambang attributed to Jayabaya. Both the ESK and MMS Aji Saka tales are in the general framework of the Serat Kanda tradition, but without elaborating the dynastic line of Sindula, Dewata Cĕngkar, and Daniswara.

ESK (pp. 10-25). Bali Aca, King of Gujrat and direct descendent of Aji Saka, because of prophecies of impending disaster sent out

${ }^{72}$ The ESK summary given here may be compared with the "Major Serrat Kanda," LOr 6379, epitomized by Th. G. Th. Pigeaud, Literature of Java: Catalogue Raisoné of Javanese Manuscripts in the Library of the University of Leiden and Other Public Collections in the Netherlands, 3 vols. (The Hague: Nijhoff, 1967-70), 2, pp. 356ff. 
his son, Awab, and daughter to colonize Java. The party landed at Bantĕn but the astrologers counseled Awab to journey to Central Java. Meanwhile Arung Bondang and his sister had been sent by their father, the King of Banda, to colonize Java. Despite the unfavorable sign of a marvelous double rainbow indicating that Java was already populated, Arung Bondang's party disembarked at Blambangan. The two groups of colonizers met at the river of Prambanan in the district of Pajang. They intermingled in a peaceful and friendly fashion. Awab married the sister of Arung Bondang and the latter married the Gujrat princess. While clearing the jungle for a permanent settlement, illness decimated the colonists. A message was sent back to Gujrat and Awab's father outfitted another expedition. Among the new emigrants were craftsmen and smiths who provided all of the necessary tools and implements including the pusaka weapons. Awab's kraton at Prambanan in the Mataram realm was constructed in the year 525 A.J. or 1208 years ago. Awab assumed the reign name Brawijaya Suwela Cala. The kingdom, already named by Aji Saka, was Mĕndang Kamulan. Suwela Cala appointed as officials the patih, Amangkurat; patih daZěm, Murdana Sraya; and jaksa, Kamandaka. During his reign he attracted foreign merchants from Siam, China, Bengal, and Moorish lands. He was engaged in constant warfare with the "giants." $\mathrm{He}$ created the wayang theatre with its stories based on his forefathers' adventures in Gujrat. Of Arung Bondang no more is heard, except that he died without male issue.

RHJ, 2, pp. 83-84, is a version of essentially the same story. Raffles attributed it to Kyahi Adipati Adimenggala and set it within quotation marks. Raffles then, pp. 85-86, gives a variant beginning: "In some of the accounts, the father of Sawela chala is named Balia Achar, and previously to the establishment of Mendang Kamulan, Sawe a Chala himself is usually known by the name of Awap." The account referred to is MMS, pp. 11-17. There are some differences in detail between the MMS and ESK. In the former, Arung Bondang was a "discontented Eastern prince" who settled Banjuwangi and from whom all later Blambangan rulers descended. A later descendent of Arung Bondang, it is claimed, contemporary with Majapait, built a large kraton just outside of Panurukan, the ruins of which are still to be seen. In the ESK, the magic symbol denoting the proper location for the Gujrat colonists was a rainbow. In MMS, it is the tunggul wulung, the magically powerful heavenly staff, that figures so often in Javanese mythological tales. In MMS, it is explicitly stated that Arung Bondang accepted the sovereignty of Awab because the Gujrat prince was the rightful descendent of Aji Saka. Middelkoop adds, and Raffles repeats, that Suwela Cala ceded Blambangan to Arung Bondang to be held by him and his descendents as an independent kingdom. He was also appointed "viceregent" over all lands eastward from Surabaya. In neither the ESK nor MMS is there a suggestion of the intervening Serrat Kanda material between the Aji Saka story and Awab's colonization of Java: the history of the Jayabaya and Angling Darma line of kings of Mulwapati.

ESK (pp. 25-29). Suwela Cala was succeeded by his son whose reign name was Brawijaya Adi Kusuma. Adi Kusuma was succeeded by his son whose reign name was Brawijaya Adi Wijaya. Adi Wijaya had five sons. The eldest was Ki Manguyu, ruler over the agriculturalists. The second was Sandang Garba ruler over the merchants. The third was Karang Kala, ruler over the woodsmen. The fourth was Tunggul Pĕtung, ruler over the palm wine tappers. The youngest son 
was Rĕsi Dangdang Gĕndis, the crown prince. On his father's death, Rĕsi Dangdang Gĕndis refused to ascend the throne destined for him, retiring instead to lead a spiritual life. This caused competition among the other brothers for the throne and eventually led to partition of the realm followed by destructive internecine warfare which threatened the continuity of the legitimate dynastic line.

The MMS, pp. 17-19, has the same story but with greater detail than the ESK. For example, Middelkoop assigns the sons of Adi Wijaya geographic seats which are repeated in the Raffles' version (2, pp. 84-85). Middelkoop also informs us that, from Adi Kusuma through Dangdang Gĕndis, the Kraton of Mĕndang Kamulan was located on Mt. Dassak, one mile from the temples at Prambanan. The author or compiler of the MMS uses the confusion on Java caused by the absence of central authority following Adi Wijaya's death to justify or comment critically on the presence of the marvelous in Javanese history:

"These are the reasons that one finds in the accounts of this island so many inconsistencies and confused opinions so much so that it is beyond human comprehension to believe that in that age men could have traffic[k]ed with spirits." This, of course, is a European reaction.

ESK (pp. 30-40). Rĕsi Dangdang Gĕndis left a legitimate son, Dewa Kusuma, who continued the dynastic line. Dewa Kusuma abandoned Mĕndang Kamulan and moved to the forest of Jĕnggala which he cleared and settled. Dewa Kusuma had five children. The eldest was a daughter Raden Rara who never married. She had as apanage Kapucangan. The eldest son was Lĕmbu Amiluhur. The second son was Lĕmbu Amiluwi of Kadiri. The third son was Lĕmbu Mangaran of Bau Warna. Lĕmbu Amiluhur extended the boundaries of Jĕnggala. Accompanied by his brothers and sisters as well as his magically powerful servants, Jati Pitutur and Pitutur Jati, Lĕmbu Amilihur journeyed overseas to India to try to win the hand of the Princess of Kling. The prophecy was that he who could wrench from the ground the magical staff, tunggul wulung, would win the hand of the princess and become the progenitor of the line of Javanese kings. Lèmbu Amiluhur's successful effort was attended by all sorts of supernatural phenomena. On the return trip to Java, he went ashore on a strange island marked by a column of smoke surmounted by a rainbow-like luminescence. On investigation he found the smoke emanated from a flat rock, which when he stepped upon it broke into four pieces. In the hollow of the stone was a frog. The frog spoke and claimed to be the future king of Java. The prince angrily ripped the frog asunder. The pieces of the carcass penetrated the flesh of Lembu Amiluhur and his brother Lěmbu Amijaya. The party returned to Java where Dewa Kusuma was overjoyed to see his children and to meet his new daughter-inlaw. While living he partitioned his realm. Brawijaya Amiluhur ruled Jĕnggala. Amiluwi ruled over Kadiri. Mangarang ruled over Ngurawan. Amijaya ruled over Singasari. Soon after Dewa Kusuma died.

Raffles' account of the reign of Dewa Kusuma and the partition of his kingdom (2, pp. 87-88) can be connected to the MSS, pp. 21-23. The--by contrast with the ESK - - rather sober treatment of Amiluhur's experiences in Kling, by Middelkoop (and hence Raffles), does not reflect the svayambara motif and the myth of the tunggul wulung narrated in detail in the ESK. The ESK version is the Pañji tale to be found in the Serrat Kanda, and was used by Brandes to compare the two texts. Raffles' 
own collection of Pañji tales (2, pp. 88-94) is independent of MMS but is interrupted ( $p .92$ ) by a communication that can only have come from MMS, p. 24, which we quote direct1y:

\section{Raffles}

About this period the first intercourse with China is believed to have taken place: a large Chinese wangkang was wrecked on the north coast of Java, and the crew landed, some near Japara others at Semarang and Tegal. The writer of the vessel is represented as bringing with him a magical stone, by which he performed many wonderful effects, and by means of which he ingratiated himself with the chief of Tegal, who allowed him to collect the remainder of his crew into a regular establishment, and conferred upon them many privileges.
Midde1koop

It happened that in this time a large China Wangkang was wrecked near Pulo Mandalika, on the Devils Rock. Of the crew, which was saved, [sic] others at Samarang and Tagal. The clerk belonging to this Wangkang was, according to the fabulous history of the Javanese, a cunning and with respect to many things well informed Chinaman, who at Pulo Mandalika found a serpentine stone, by means of which performed numerous wonderful acts. On his arrival at Tagal, he first excited the compassion, and afterwards insinuated himself into the favor of the Regent of that place, in so high a degree that he obtained leave to settle there with his companions, and to call the rest from... and Samarang, but a piece of land was also given to them to build upon and many privileges granted.

According to Middelkoop this was the origin of Chinese settlers on Java. There is a lacuna in the ESK (Chapter 3, p. 31, paragraph 36) in both the Dutch and English manuscripts. On the bottom of the page of the English translation, on which paragraph 36 appears blank, a note is penciled in giving the date of the establishment of the kraton at Jenggala by Dewa Kusuma as $785 \mathrm{~A} . \mathrm{J}$. or 950 years having elapsed to the year 1807.73

ESK (pp. 41-47) Lĕmbu Amiluhur's first son was Pañji Kĕrtapati. Hence, the prophecy of the frog was fulfilled. The frog was an incarnation of the Lord Wisnu. Kertapati was a wise and brave crown prince. He forced Bali, Sambor and other islands to submit to Java. On attaining marriageable age he was espoused to his cousins, Sĕkar Taji of Kadiri, Kumaningrat of Ngurawan, and Nawang Wulan of Singasari. Pañji succeeded to the throne having the reign name Brawijaya Kĕrtapati. He had a son by his Kadiri consort whom he named Pañji Lalean. By his second wife, Kumaningrat, he had a son, Citra Angrung Baya, who became the ruler of the spirits at Tunjung Bang. After Lalean had ascended the Jĕnggala throne a great plague, attributed to the spirits of Tunjung Bang, devastated the country. Pañji Lalean abandoned his kraton and moved to the forest of Blora in the southwest. There he founded a new kraton called Mĕndang Kamulan, which name had originally been carried by Prambanan. This occurred in 994 A.J., from which time 740 years have elapsed to the Dutch year 1807.

${ }^{73}$ The possible source for this interpolated date is the "Register" appended to Private Collection, 23, vol. 3, pp. 349ff. 
MMS, pp. 24-27, has the same frame story but differs in some details. Kertapati, for example, has only two wives, Nawang Wulan of Singasari not being mentioned. The expulsion of the raja of Prambanan (alias Mĕndang Kamulan) to Pajang Pengging near Surakarta by Pañji Kĕrtapati is noted. Citra Arum Bayu, in conspiracy with his magician father-in-law, is blamed for the disaster at Jěnggala. RHJ, 2, pp. 94-95, condenses the MMS material but its direct dependence on it is clearly evident. For example:

$$
\text { RHJ , 2, p. } 95
$$

The sickness having continued to prevail after the departure of the prince, the inhabitants who had remained at an early period, are said to have embarked in vessels and proceeded to sea, no one knowing whither they went or hearing more of them.
MMS, p. 26

The diseases meanwhile continued after the Rajahs departure, wherefore many inhabitants that hated Boko, and for that reason did not follow that Prince, went to sea with an intention to settle elsewhere, yet they have never since been heard of.

\section{The ESK resumes the narrative:}

ESK (pp. 47-80). Lalean was deposed by his patih, Baka. He took refuge with a magically powerful sage on Mt. Kĕlud, marrying his daughter. Baka, now ruler of Mĕndang Kamulan, had two daughters. A courtier named Bandung was promised the hand of the elder if he could perform in one night miraculous tasks. In the course of the night he killed his mother because she could not help him. For this he was cursed and turned into a dog. The princess was banished from the kraton because she resisted the unnatural lust of her father. She was locked away with her weaving. One day she dropped her shuttle and cried out she would marry whoever recovered it. The dog (Bandung) jumped the fence of her enclosure and brought it to her. obliged by her vow she became his wife. It is from this union that the race of the Kalang people spring. Baka's youngest daughter, Kumarawati, was promised to him who could bring as a wedding gift a golden locust possessing human speech. The ruler of Giling Wêsi in Pajajaran, Purwa Catur, took this demand as a refusal of his suit and was angered. He and his sister, Ambarawati, who ruled the spirits of the region, were descendents, through an illegitimate line, of the former Prambanan king, Adi Kusuma. Purwa Catur marched to war against Baka. The Mêndang Kamulan ruler sought allies throughout Java, promising again his daughter's hand. On Mt. Kĕlud, the holy man prophesied that the refulgent gleam of royal dynastic power, sěkti, would leave Měndang Kamulan to once again envelop Lalean. Lalean, calling himself Kuda Tilarsa, hastened to the battlefield at the river Sabda. Aided by invisible allies on both sides, the two armies met. To decide the contest of the two commanders, Purwa Catur and Kuda Tilarsa, fought in single combat. Ambarawati came to the aid of her brother and enchanted Kuda Tilarsa, reducing him in size and placing him in the magical container, the manik astagina. Kuda Tilarsa's two magically dangerous servants went to the God Indra on Mahameru for assistance. Once, in the service of his father, Lalean had waited upon the God. At that time he married Indra's daughter Dewi Supraba and had had a son, Raden Pañji Indra Kusuma. Indra dispatched his grandson to Kuda Tilarsa's aid. Meanwhile Baka had fled his kraton leaving Kumarawati behind. She was taken under the protection of Indra Kusuma. When Purwa Catur arrived to claim her he 
was engaged in combat by Indra Kusuma, who killed him. Ambarawati tried to revenge her brother but in the course of her combat with Indra Kusuma she was robbed of the manik astagina, the source of her magical power. Lalean, now released, recognized his son and blessed his marriage to the conquered Ambarawati.

The marvalous history of Lalean, as recounted in the ESK, is considerably condensed in MMS, pp. 27-33, and stripped of much of its supernatural detail and embellishment. The way in which the story is told by Middelkoop heightens the impression that not only was he summarizing and translating from a Javanese original(s), but that he was straining the material through European critical faculties editing out, to some extent, the fabulous and miraculous. It is the MMS version that can be identified in RHJ, 2, pp. 95-96. In both, the narrative of Lalean's war against Baka (not, as in the ESK, Purwa Catur's war) is interrupted by a side adventure which is not in the ESK.

$$
\text { RHJ, 2, p. } 96
$$

Kuda Lalean, having been requested by the chiefs of Banyu Mas, Lurung Teng' $a$, and Tegal to render them assistance against the Chinese, who, by their extortions and oppressions, had thus early become troublesome to the people of the country, attacked them, and killing their chief, relieved the inhabitants of these districts from their oppressions. From this period the Chinese have been dispersed over the whole island.

To pick up in the ESK again:
MMS, pp. 32-33

When Lalean was ready to commence his march, he was solicited by the Prince of Banjoomass, of Loorang Tengo and Tagal to afford them assistance against the Chinamen, whose estorsions [sic] and oppressions they were unable any longer to support; and having complied with that request, he was happy enough to conquer the Chinamen, killed their chief and delivered the inhabitants of these countries from their oppressors. Since that time the Chinamen were dispersed over the whole island.

ESK (pp. 80-89). Lalean laid a curse on the 1and of Mĕndang Kamulan rendering it uninhabitable forever more. The destruction of Měndang Kamulan and Giling Wěsi took place in 1027 A.J. being 707 years to the Dutch year 1807. With his wife from Mt. Kĕlud and his new wife, the Princess Baka, Lalean journeyed west to found a new kingdom in the forests of Pajajaran in the northeast of the former Giling Wesi. While clearing the forests he was afflicted with an eye disease. His new wife tried to kill him by preparing a poisonous salve in order to hide an adulterous affair. The poison only had the effect of curing him. Seeing this she fled with her lover. In time the Pajajaran forest became a rich and fertile land. Lalean acquired the pusaka cannons, Ki Jaka Pĕkik and Ni Stommi, the transmogrified bodies of the parents of the twins Antang and Anting. Lalean was hailed as king of the growing and prosperous country of Pajajaran.

MMS, pp. 33-36, is again a more sober version of the same frame story as the ESK. Its connection to Raffles' version is unmistakable:

$$
\text { RHJ , 2, p. } 96
$$

This prince was a great promoter of agriculture, and encouraged the common
MMS, p. 33

Rajah Lalean was a great promoter of agriculture, encouraged the common people 
people in the labours of cultivation by his personal example. He was the first who introduced the rice husbandry into the western provinces. by his own example, so that within the space of a few years many rice fields were laid out in places which before his time were barren.

\section{The ESK continues the "history" of the Pajajaran kraton:}

ESK (pp. 89-105). After a long and prosperous reign Lalean died. He was succeeded by his youngest son, Munding Sari. His oldest child was a daughter, Njai Gĕde Tĕmpe Mas, an ascetic. His oldest son went to Mecca and adopted Islam. After some years he returned with the name Haji Purwa and sought to convert his brother and sister. $\mathrm{Njai}$ Gĕde Těmpe Mas was able to demonstrate that indigenous magical/spiritual power was stronger than Haji Purwa's new religion. Shamed, he returned to Mecca. The kraton was blighted as a result of the contest and Munding Sari was forced to move it to the northern part of Pajajaran. Munding Sari was succeeded by his son, Brawijaya Munding Wangi. Munding Wangi had four children. The oldest was a daughter who became queen of the spirits of the South Seas. The second was a daughter afflicted by leprosy. She was banished to Pulau Putri from where she was carried off by a European. The third child was a son, Arya Banggah who was named regent of Galuh. The youngest was a son named Raden Tanduran. In the course of a dispute Munding Wangi killed a magically powerful seer who after death prophesied that a child borne by a concubine would take revenge. When the baby was born it proved invulnerable to the ruler's efforts to kill it. Then follows the history of Siyung Wanara, alias Banyak Wide, who lived to grow up and kill his father and become ruler of Pajajaran.

Both the ESK and MMS, pp. 36-42, abbreviate the Pajajaran line of kings. The Serrat Kanda and BTJ tradition identify in order of succession: Lalean, Banjaran Sari, Munding Sari, Munding Wangi, and Sri Paměkas. Arya Banggah, Raden Tanduran (a1ias Susuruh, the founder of Majapait), and Banyak Wide are the children of Pamekas. This deviation from the "canon" was noted in the ESK by Brandes, and may, in part, have inspired his suggestion that Raffles might have had it as a source. Since the same dynastic order is given by Middelkoop, Raffles' incorporation of it can be explained otherwise. Although this again demonstrates that the ESK and MMS derive from the same general "historical" foundation, they continue to differ in detail. The story of the diseased princess is more elaborate and specific in Middelkoop's version. She was carried off by a Portuguese trader by whom she had two daughters, one of whom married a Dutchman, the other an Englishman. According to Middelkoop, there was a prophecy that descendents from these two unions would at one time or another rule over all of Java. If this prophecy was part of a Javanese original, then it would help date Middelkoop's sources. On the other hand, it is possible that it is an interpolation by Middelkoop himself, putting the English regime in the framework of the Javanese traditional history. Raffles notes only that the princess was carried away by "white men" without specifying their nationality.

ESK, pp. 106-232, details the history of Majapait. MMS, pp. 43101 , covers the same period but shows some important structural differences. Brandes, commenting on Raffles' treatment of the Majapait period stated that: "It is regrettable that Raffles did not document in an orderly way the sources of his information or from whom he 
learned it. Even so, it must be acknowledged that on this point again he achieved a remarkable comprehensiveness for his time."74 Brandes' encomium was really earned by Middelkoop, on whose effort Raffles' treatment was primarily based.

ESK (pp. 106-29). History of the foundation of Majapahit. Raden Tanduran unsuccessfully tried to avenge his father and was forc's to flee from Pajajaran to the East. He takes refuge with the widow of Kali Gunting. Episode of the prophecies given by the doves (burung përkutut). After three months Tanduran goes further east accompanied by the widow and her three brothers, Wira, Nambi, and Banjar. They followed the flight of the doves as they were directed to by an ascetic. At the site of a Maja tree embraced by a vine bearing bitter (pait) fruit, they settled. The date of the construction of the royal quarters was $1021 \mathrm{~A} . \mathrm{J}$. [sic] since which time till the Dutch year 1807 A.D., 513 years have elapsed. Tanduran's elder brother, Arya Banggah of Galuh revolted against Siyung Wanara. Arya Banggah was routed and forced to flee eastwards across the river Pamali and thence to his brother at Majapahit. Tanduran adopts the title Brawijaya Tanduran. His brother is made pangeran with the title Arya Panular. Wira, Nambi, and Banjar become officers of the court. Pajajaran is scourged by a plague and famine. All of the smiths of Pajajaran emigrated to Majapahit. Siyung Wanara sent his army in pursuit of the smiths. The armies of Pajajaran and Majapahit met and for five months battled. Just as Siyung Wanara and Brawijaya Tanduran were to enter into single combat a mysterious voice from heaven enjoined them from further fighting and indicated the boundary between the two kingdoms. In Majapahit the Pajajaran smiths fabricated the pusaka cannon, Gunter Gĕni. After a number of years of a prosperous reign Tanduran died and was succeeded by his son Brawijaya Kumara. When Siyung Wanara died the realm passed to Majapahit authority and the Pajajaran pusaka came to Majapahit.

MMS, pp. 43-47, is essentially the same version except that the final miracle has been dropped; there is no voice from the heavens. The single combat between the Pajajaran and Majapait kings is interrupted by an old priest who stipulated the terms of peace. Middelkoop also notes that Banggah, alias Panular, was made regent of the territory along the Solo River. RHJ, 2, pp. 98-99, can be connected to the MMS. Both follow with the story of Torbito:

An ineffectual attempt was made by Ratu Dewa, a native of Kuning'an in Cheribon, who, on the departure of Aria Babang 'a, had been entrusted with the administration of Galu, to maintain an authority independent of Majapahit; but he lost his life in the struggle, and his wife, Torbita, who persevered, and was for a time successful, was at length overcome, and went over to Majapahit. (RHJ, 2, pp. 99-100)

This is an abbreviated tale from MMS, pp. 48-49. In Middelkoop, however, Torbito had a son, Rano Sukarian, who had an incestuous love for his mother. She fled to Majapait to seek the Raja's protection from the son.

74 Brandes, Pararaton, p. 202. 
ESK (pp. 130-55). Brawijaya Kumara's reign was fortunate but short. He was succeeded by his son Brawijaya Adi Wijaya. Adi Wijaya plotted against his chief minister, Teja. Teja was murdered by Menak Sopal, chief of the king's life guards. In retaliation Lampah Teja, the murdered patih's son, ambushed the king in a forest one day when he lagged behind in the hunt. The successor was Mĕrta Wijaya who appointed Gaja Mada as chief minister. Because of the dolorous circumstances of the king's death and the bad omen it represented the kraton was moved to the southeast of Tuban, retaining, however, the name Majapahit. This occurred in $1321 \mathrm{~A} . \mathrm{J}$. from which year to the Dutch year 1807 A.D., 413 years have elapsed. During Mĕrta Wijaya's reign the pusaka kris, Jalak Sumĕlang Gandring was stolen and delivered to the regent of Blambangan, Menak Dalih Putih. The chief Majapahit smith, Ki Supa, was able to penetrate the Blambangan court undercover, and by subterfuge and trickery recovered the kris. With the kris safely in hand Mĕrta Wijaya ordered his army, under the command of Lěmbu Sora, against Blambangan. Menak Dalih Putih was killed in hand to hand combat with $\mathrm{Ki}$ Supa, who had been named regent of Sidayu as reward for his services. Měrta Wijaya died and was succeeded by his son Angka Wijaya, the fifth and last ruler of Majapahit.

Both RHJ, 2, p. 109, and MMS, p. 50, say more about the fate of the Pajajaran smiths in Majapait. The relationship between the two texts is self-evident:

\section{Raffles}

Under the second prince of Majapahit called Brohmara or Brow'yaya the second, the manufacture of arms of various descriptions was brought to the highest perfection; and the first damasked krises were now made by the pandi (smiths) from Pajajaran who became so distinguished that they were appointed to the charge of districts with a thousand cha cha each. The kris which was afterwards placed on the tomb of Susanan Giri is said to have been manufactured at this time from a piece of old iron found by the prince.

\section{Middelkoop}

Under the reign of this prince manufacturing of arms was brought to great perfection and the first damasked krises were made by some of the smiths that had come over from Pajajaran named Ki Supa, $\mathrm{Ki}$ Petrang, Ki Jaka, Ki Kelang, who in recompense therefore were appointed regents over districts containing one thousand cacas of rice land. One Kris was made of a piece of old rusty iron found by the prince himself near the Kraton. This Kris was named Dapu Kala Munjang and remains among the pusakas of the emperor of Java, although he denies it, having obtained it in an indirect manner.

This "indirect manner" connects the kris to Sunan Giri for, according to MMS, p. 50, the kris, which was stolen in 1776, was buried with Sunan Giri in a separate box near his corpse. It was rumored that the Surakarta ruler instigated the theft. According to Middelkoop, the Dutch Governor-General, Van der Burgh, disturbed by the political implications, had another old kris substituted, bribing the attendants of Sunan Giri's tomb to accept it. RHJ, 2, p. 111, notes the subjugation of the king of Singapura and the ruler of Indragiri. These communications are drawn from MMS, p. 52 and p. 54. RHJ, 2, p. 111, comments that:

Accounts differ regarding the successor of this prince [Merrta Wijaya] some considering Raden Alit, his brother, to have succeeded at an 
early age and others that Raden Alit is the same with Angka Wijaya, the last sovereign of Majapahit. According to the latter account, many of the principal events reported to have taken palce in the reign of Alit are brought under that of Merta Wijaya.

This is exactly the relationship between the ESK and MMS. According to the MMS, p. 54, Merta Wijaya died childless and the throne reverted to his brother, Alit Wijaya. It was during Alit Wijaya's reign that the war against Dalih Putih of Blambangan was waged. MMS, p. 59, tells us that, when Alit Wijaya died, he was succeeded by his son Angka Wijaya, the last king of Majapait. In his detailing of Majapait history Raffles followed Middelkoop:

$$
\text { RHJ , 2, p. } 111
$$

Through the wisdom of the minister, Gajah Mada, who was continued in of fice and the prudent direction of Alit Wijaya, the Kingdom of Mojopohit rose to the highest pitch of wealth and glory. Several nations on Sumatra and among them the people of Palembang, as well as the inhabitants of the southern states of Borneo, who had no regular government at the period obtained from him protection against the people of Lampung, and in return acknowledged the supremacy of Mojopohit.
MMS, pp. 54-55

Through the wisdom of the Prime Minister Arya Gaja Mada, and the prudent direction of the Rajah, the kingdom of Maja Pahit rose to the highest pitch of wealth and glory. Some nations on the Island Sumatra, Palembang, likewise the inhabitants of Borneo, who had no regular Government, applied for protection and help against the people of the Lampongs, who were very troublesome and captured and plundered their subjects. Their application was granted, and the enemy subdued, since which time the Rajah of Maja Pahit became protector and afterwards Sovereign of Palembang and Borneo.

The MMS and ESK outlines of traditional Majapait dynastic succession can be compared to the BTJ and the "Major Serat Kanda."

MMS

Tanduran Brawijaya II Kumara Adi Wijaya Mĕrta Wijaya Alit Wijaya Angka Wijaya
ESK

Tanduran

Kumara

Adi Wijaya

Měrta Wijaya

Angka Wijaya
BTJ

Susuruh

Anom

Adiningkung

Ayam Wuruk

Lembu Amisani

Bra Tanjung

Brawijaya (Alit)
SK

Tanduran (Jaka Suruh)

Kumara

Adi Wijaya

Adiningkung

Prabu Kenya

Angka Wijaya

Among the dynastic 1 ists published by Raffles is one identical to the ESK list given to him by Adimenggala (RHJ, 2, p. 82). This accords with the suggestion that the ESK originated in the Semarang kabupaten.

Raffles' account of the Blambangan War (RHJ, 2, p. 112) conforms to the MMS, pp. 55-58. Raffles does advert to the Damar Wulan romance which is not included in either the MMS or ESK. On the other hand, the RHJ paragraph on the same page, calling the population of the Sunda Straits region the "dregs of all nations," is nearly word-for-word from the MMS, p. 59.

ESK (pp. 155-97). History of Angka Wijaya. He had a son by an ogress. The son was named Raden Dilah. Angka Wijaya married a 
princess of Cĕmpa. Putri Cĕmpa was jealous of the king's Chinese concubine. In order to amuse Putri Cĕmpa the king had Raden Dilah collect wild animals and construct a pleasure garden. Raden Dilah was promoted to the rank of Arya Damar. In Bali a hog-headed king named Dewa Macuwet reigned. He had two brothers: Maya Denawa who was tusked-jawed and Kĕbo Wiwaha a giant Demon. Dewa Macuwet demanded a Majapait princess for his brother Kĕbo Wiwaha. A portrait was painted of a beautiful woman who was represented to the Balinese as the princess. Deceived, the Balinese sent a wedding party to Java. A likeness of the supposed princess was shaped from clay and placed in a valley between two mountains. On the slopes of the mountains the Javanese had gathered firewood and prepared quantities of slaked lime. In the illumination of the night fires Kĕbo Wiwaha thought the statue was in fact the princess. The patih, Gaja Mada, passed to Kĕbo Wiwaha the request of the "princess" that he dig her a bathing pool at the foot of the mountains. Ambushed in the huge pit he had dug, Këbo Wiwaha died under the onslaught of fire, ashes, stones and lime cast down on him by the Majapaiters. Arya Damar then led an invasion of Bali and eventually killed Maya Denawa and Dewa Macuwet. Sang Dewata Agung, the son of the dead Balinese king, ruled Bali as a vassal of Majapait. Arya Damar was rewarded by being appointed Adipati of Palembang. He was given the Chinese concubine as wife. She was already pregnant by the king. When the child, a boy, was born in Palembang he was named Raden Patah.

Both the RHJ, 2, pp. 115-16, and the MMS, pp. 59-63, agree with the main 1 ines of the ESK narrative of Angka Wijaya's marital complications and the origins of the Balinese War. Within the general mythic framework, however, the MMS is, as usual, more sober. For instance, it suggests a pragmatic policy reason for the presence of Putri Cina at the Majapait court--she was sent there by Canton merchants in order to obtain trade privileges (p. 60). MMS, p. 68, also reports that the sister of the dead Balinese king was delivered to Majapait as a concubine. This has later relevance.

ESK (pp. 197-211). The histories of the Islamic saints of Java. Raden Said Rachmat of Cempa (located in Borneo) was the son of the Arabian prophet Haji Mustakim and the daughter of the King of Cermpa. He was sent to Java where he became the Susuhunan of Ampel. Sunan Ampel confirmed Maulana Jumadil Kabra as the Susuhunan of Kali Sapu, from whom are descended the Sultans of Ceribon and Banten. Maulana Said Iskak arrived on Java from Malacca. He was sent by Sunan Ampel to Blambangan to propagate the faith. He abandoned his pregnant wife and returned to Malacca. His son grew up to be the Susuhunan of Giri, married to one of Sunan Ampel's own daughters. Maulana Caliph Husseun of Arabia was sent by Sunan Ampel to Champang to be Imam. A son of Sunan Ampel was sent to Tuban as Imam, becoming Sunan Bonang. Another son of Sunan Ampel was placed in Sidayu and appointed Sunan Drajat. Raden Patah made a pilgrimage to Ampel where he was converted to the faith. He married a granddaughter of Sunan Ampe1. He was directed by Sunan Ampel to go to the wood Bintara Wangi in the district of Demak to found a settlement. A nephew of Sunan Ampel was sent as Imam to Kudus with the title Sunan Undung. After this a fourth Maulana, named Abdullah, arrived in Java from Arabia. He was placed by Sunan Ampel in Semarang which was then called Pulau Tirang. Sunan Ampel prophesied that Semarang in the future would be a great land and a great emporioum, the residence and trading mart of the 
people of many nations. Semarang would remain the property of Abdullah and his descendants. Raden Said, a noble disciple of Sunan Bonang, was sent to Ceribon and became Sunan Kali Jaga.

The stories of the sainted apostles of Javanese Islam, the wali, are an important part of the Javanese traditional history of the last days of Majapait. The specifics of the tales vary from tex to text depending on the locality or noble family being honored. The ESK narration of the introduction and proselytizing of Islam on Java is brief and devoid of magical embellishments. Sunan Ampel's prophecy about Semarang gave legitimacy to the local bupati. The main difference between the ESK and MMS is in the background of Sunan Giri. The MMS places Sunan Giri's father, Iskak, at Arya Damar's Palembang court, not Blambangan. In the MMS, Sunan Giri was sent away from Palembang as a youth because of the court's hostility towards Islam. In neither the MMS or ESK does Sunan Giri or his descendants loom as large as in the BTJ tradition.

ESK (pp, 211-14). Angka Wijaya of Majapait had numerous children: by Putri Cèmpa a daughter, Andaya Ningrat, married to the regent of Pengging; a son, Lěmbu Pĕtteng, named regent of Champang on Madura; a son, Raden Gugur. The regent of Pengging had shown bravery in putting down the second Balinese revolt. Angka Wijaya's eldest illegitimate son was placed on the Balinese throne as Dewa Kĕtut. A second illegitimate son, Bĕtara Katon was made regent of Panaraga. An illegitimate daughter became regent of Locana in Mataram. Another daughter was married to Jaran Panole. A third illegitimate son, a suckling named Bondan Kadjawan, a child of a princess of Banda, had been turned over to the care of a peasant named Ki Paswahan. The king prophesied that the descendants of that child would have sovereignty over Java with their courts at Mataram, Kartasura, and finally Surakarta in Pajang.

The MMS, pp. 76-79, agrees with the ESK enumeration of Angka Wijaya's progeny although giving more detail. Andaya Ningrat married the daughter of Putri Cempa as a reward for his services against Bali. Dewa Kĕtut, the illegitimate son placed on the Balinese throne is identified in the MMS as the son of the Balinese princess taken at the end of the Balinese War. Lembu Petang was appointed Panembahan of Madura and was accompanied there by Caliph Hussein alias Pangeran Sarif, a fact also noted in RHJ, 2, p. 121. The RHJ's statement on the Bali revolt, which is almost word-for-word from the MMS, p. 76, is preceded by a description of the career of Sunan Gunung Jati which is drawn from the MMS, p. 85. The MMS carries the story of Bondan Kajawan up through his grandson, Jaka Sĕsela. The descendants of Bondan Kajawan are not taken up in the ESK until much later.

ESK (pp. 214-32). Arya Damar had a son Raden Husen. He became a courtier at Majapait and was appointed adipati of Tĕrung. Meanwhile Raden Patah was founding a settlement at Bintara. Raden Patah accepted the advice of his half-brother Adipati Terrung and presented himself at court and was recognized as son by Angka Wijaya. He was appointed Adipati Bintara. Raden Patah consulted his "grandfather" Sunan Ampel about the propriety of attacking Majapait. Sunan Ampel counselled against it. It would be in violation of his obligations, and that the king, although not a Moslem, had been virtuous. Shortly thereafter Sunan Ampel died. The date was Javanese 1425 A.J. or 309 
years ago [1498 A.D.]. In 1429 A.J. the great mosque at Demak was built. In 1431 the mosque at Ceribon was built. Then the walis held a council and agreed to support Adipati Bintara in an assault on the throne of Majapait. The supreme commander of the Moslem army was Sunan Undang. After many magical signs and encounters the army of Majapait was defeated. After peace and order had been restored Adipati Bintara was proclaimed by the walis ruler of Demak with the reign name Panĕmbahan Jimbun.

Both the ESK and MMS differ in some significant respects from the BTJ account of the fall of Majapait and the founding of the first Moslem Javanese state. In the former two, Sunan Ampel, the senior Islamic apostle is depicted as being opposed to Raden Patah's planned war of conquest, whereas in the latter, it is Ampel that hails Patah as the legitimate successor of Majapait. The end of Angka Wijaya is also given differently. In the BTJ it is said that he disappeared from the phenomenal world along with his followers, a well-known motif in Javanese dynastic myths, while simultaneously the magical power of kingship descended as a lightning bolt in Bintara (Demak). Both the ESK and MMS relate that Angka Wijaya fled to the east of Java where he tried to rally his forces. After a new expedition from Demak, under the command of Sunan Kudus and the converted Adipati Terung had inflicted a second defeat, Angka Wijaya ultimately found refuge on Bali with his son, Dewa Kětut. In the BTJ tradition Sunan Giri figures prominently whereas in the common tradition of the ESK and MMS he is relegated to the background.

ESK (pp. 250-310). Enumeration of the children of Panĕmbahan Jimbun. The story of the murder of Kĕbo Kĕnanga (Ki Agěng Pĕngging). Kĕbo Kĕnanga was suspected by the Sultan of Demak of conspiring against him. Sunan Kudus was sent to do away with him. The men of Pĕngging pursued Sunan Kudus' band but were magically deceived. Seven days after Kĕbo Kĕnanga's murder, his wife followed him in death. Their orphaned five month old son, Raden Krĕbet, was placed in the care of Nyahi Gĕde of the desa Tingkir. Panĕmbahan Jimbun died in the Javanese year 1449, after ruling in Demak for nine years. He was succeeded by his son Pangeran Sabrang Lor who died after only two years. While the walis were consulting at the Demak Mosque over the succession a certain Gĕde Sela caught a lightning bolt striking at the Mosque. It was decided that the younger brother of the late Panĕmbahan Raden Trĕnggana, would be installed as Sultan of Demak. This occurred in the Javanese year 1451. Sunan Kudus was made penghulu. The Widow of Tarub adopted a foundling magically appearing on her husband's tomb surrounded by a refulgent aureole. She called him Kyahi Tarub. Kyahi Tarub became the adoptive father of Bondan Kajawan. By his wife, a nymph, he had a daughter with whom Bondan Kajawan was married. Their son was Kyahi Gěde Gĕtas Pendawa. His son was Ki Gĕde Sela, the one who had caught the lightning bolt at the Demak Mosque. Ki Gĕde Sela entered the service of the Sultan of Demak but later went into rebellion. In a face to face confrontation with the Sultan, Ki Gĕde Sela was shamed. The Sultan ordered him to return to his village, prophesying that one of his descendants would show more courage. Raden Krĕbet, son of the murdered Kĕbo Kĕnanga, was more commonly known as Jaka Tingkir. One day he had a vision in which Sunan Kali Jaga appeared, informing him that it was his destiny to become King of Java and to go take service with the Sultan of Demak. He became an adoptive son of the Sultan and chief of the 
bodyguards. Because Jaka Tingkir killed a stranger without proper cause the Sultan caused him to be banished. For seven months in the forest Jaka Tingkir became the disciple of the holy men Ki Gĕde Buta and Ki Gĕde Ngarang. At the grave of his father in Pĕngging he had a vision telling him to join the hermit Ki Gĕde Bañju Biru. Ki Gĕde Bañju Biru prophesied that Jaka Tingkir would be King of Java at Pajang. ter three months of instruction Jaka Tingkir was ordered to return to Demak and by guile reenter the service of the Sultan. Along the route back Jaka lingkir and his comrades had a marvellous adventure with crocodiles. Jaka Tingkir was restored to the Sultan's good graces. Sultan Demak journeyed to Ceribon to bring Sunan Kali Jaga back to Demak where he was given the district of Adilangu. The Sultan of Demak had six children: a daughter married to the Panermbahan of Bantĕn; a daughter married to a son of Kyahi Gĕde Sampang of Madura; a son, Pangeran Arya; a daughter married to Pangeran Kali Njamat; a daughter married to Jaka Tingkir, whom he appointed regent of Pajang; a son, Raden Timor. A nephew, Arya Panangsang, was named regent of Jipang. At the death of the Sultan, his son-in-law, Adipati Pajang (Jaka Tingkir) succeeded him. This happened in the Javanese year 1501, 233 years having elapsed to the Dutch year 1807.

Raffles' Chapter 11 (Vol. 2, pp. 135ff.) begins with an account of reigns of the first three Demak Sultans, Jimbun (I), Sabrang Lor, and Raden Trenggana (Jimbun II). It is an extremely compressed version of MMS, pp. 102-7. The RHJ account of the death of Kabu Kanigara (Kĕbo Kenanga) given in quotation marks on pp. 135-36, which is there attributed to "native writers" is to be found on pp.104-5 of MMS. The RHJ advertence to Jaka Tingkir's history is an abbreviation of MMS, pp. 107-13. Raffles notes the explo1ts against "alligators," a struggle fully described in MMS, pp. 112-13.

\section{Raffles}

Several exploits against alligators are recorded of him; and the opinion that no descendant of the princes of Pajang need fear injury from these animals is so prevalent, that it is not unusual for a Javan of the present day, seeing himself in danger from one of them to exclaim aloud that he belongs to that family.

\section{Middelkoop}

From that time until now it is a prevailing opinion with the Javanese, that no descendant of the Prince of Padjang need fear any hurt from alligators, and if a Javanese were to see some of these animals at a distance, he would call out to him and declare himself one of that family.

There are minor differences in detail between the MMS and the ESK. In the MMS, for example, there is no suggestion of Sunan Kudus's magic in evading the pursuing hosts of Pengging. The genealogy of Ki Gede Sela tracing him back to Bondan Kajawan, and hence Majapait, appears earlier in the MMS than the ESK. Unlike the BTJ tradition, neither the ESK or MMS identify Kěbo Kĕnanga as a disciple of the wali Siti Jĕnar. In the context there of religious heterodoxy, Sunan Kudus's role as executor of God's will is more intelligible.

Before taking up the history of Pajang, the RHJ has a paragraph (2, pp. 138-39) on the division of Ceribon after Sunan Gunung Jati's death. This is an example of Raffles' reordering of topics in his working of the Middelkoop materials. In the MMS the original passage from which Raffles drew is found on $p p$. 137-39, inserted in the narra- 
tive between the death of Raden Panangsang and Sultan Pajang's pilgrimage to Giri. Middelkoop, on the other hand, interrupts the historical narrative at this point (MMS, pp. 116-21) with an incidental account of the origin, customs, and myths of the Tenggerese, a subject with which Raffles dealt elsewhere.

With the history of Pajang we reach the point in the ESK from which De Graaf has already surveyed. We will therefore limit ourselves to some further comments on the relationship between the RHJ and the MNS and the increasingly divergent view of the MMS and ESK, through the reign of Senapati. The RHJ, 2, pp. 139-41, sketches the early history of Pajang--the murder of Prawata by Raden Panangsang's henchmen, and the eventual revenge by Sultan Pajang's forces. This should be compared with MMS, pp. 124-35. The passage given in quotation marks by Raffles, 2, p. 141, describing the way in which Raden Panangsang was ensnared by his own temper and rode into a trap which cost him his life, is nearly identical in wording to the MMS paragraph describing the same event:

\section{Raffles}

At this summons the Raden came forth in a great rage, and ordering his horse and spear, galloped down to the riverside and called upon the prince to come over to him; but the chief of Pajang answered, that if he was the man of courage he pretended to be, he would himself cross to the side he occupied. The Raden, accompanied by two. Panakowans only, then crossed the river, and inquiring for his opponent was informed that he remained in his pondok, and had sent his son to fight in his room, and would only appear in the event of his being conquered. Raden Penangsang then said with a contemptuous smile, 'Is the Brebo Pateh afraid, that he sends me a child with whom he knows I will not fight, I will teach him something. . . .

\section{Middelkoop}

. . and when the Radeen had read the letter he burst out into the most violent rage, ordered his horse and took a lance and galloped down to the riverside, calling that the Brebo Patty should come over to him to which Pamanahan replied, that if he really was a man of so great courage as he pretended to be he ought to go and find the Brebo Patty. The Radeen, accompanied by two Pannakawans only went over the river, but when he asked for the Brebo Patty they told that he was in his Pondak, but had sent his son to fight in his place, and would only come if the latter happened to be conquered. Radeen Penangsang said laughing, is the Brebo Patty afraid that he sends me a child, with whom I will not fight? Yet I will teach him something. . . .

This passage as well as again confirming Raffles' "borrowing" of Middelkoop's material, also suggests a possible relationship between the MMS in the Mackenzie Collection and the manuscript at Raffles' disposa1. Throughout the comparison of the RHJ and the MMS minor variations in language are encountered, but the dependency of the former on the latter is evident. In the last cited example we have the interesting statement from Raffles that while Pajang (the Brebo Patih of the texts) rested in his pondok (a temporary shelter) he had "sent his son to fight in his room [italics added]." The MMS reads: "Had sent his son to fight in his place [italics added]." The RHJ statement makes sense only as an error in too rapid translation from a Dutch original that probably read: "in zijn plaats." The hypothesis here is that the text Raffles had and Mackenzie's MMS were independent translations of the same Dutch text. This would explain the many other discrepancies. 
Raffles, 2, pp. 142-43, chronicles Pajang's journey to Giri 1490 A.J., the prophecy that Kyahi Gede Mataram's descendant would rule Java, and the administration of Mataram to his death, 1497 A.J. This is equivalent to MMS, pp. 139-46. The two dates, 1568 A.D. and 1575 A.D. deserve mention since they differ from those given in the BTJ and related traditions: A.D. 1581 for the Giri pilgrimage and 1584 for Mataram's demise. De Graaf called attention to the fact tha two dates for Pajang's journey to Giri were current. "The first," he wrote, "we have Raffles to thank for." The second date, 1581, appears in the "reliable" Babad Sengkala, the less reliable Babad Momana, as well as the Babad Tanah Jawi. According to De Graaf, "Because Raffles did not mention from where he had drawn his information, we should give preference to the three unanimous Javanese texts."75 In fact the source of the date is MMS, p. 143. Not only are the dates different, but the intervalsbetween them do not agree. For the babad tradition only three years; in Middelkoop's source $(s)$, seven years.

RHJ, 2, pp. 144-49, outlines the history of Senapati and the foundation of Mataram's greatness. From the Raffles text the cause of Senapati's estrangement from his Pajang sovereign is not clear. In the BTJ and ESK there is also no precipitant cause stated. It is a developing pridefulness and sense of destiny that stokes Senapati's arrogance toward Pajang. As we have noted, the MMS seems to be closer to the ESK version of Javanese history than the BTJ tradition, but it is apparent, particularly as we move into the Mataram period, that it too draws on autonomous indigenous sources and has historiographical value in and of itself. This is evident, for example, in the details of l'affaire Pabelan (or Panalan) which in the MMS version is the proximate cause of Senapati's hostility towards Sultan Pajang. In the BTJ and ESK it is treated as a minor irritant occurring late in the unfolding antagonistic relationship between Pajang and Mataram. In the MMS we read:

The Island of Java was then already much frequented by Portuguese Navigators who had established a Factory at Bantam.--Peace reigned from without but the interior dissensions caused by a number of small independent Chiefs or Princes, who contended for Supremacy, disturbed the general tranquility.--Among those, who above all others distinguished themselves for their ambitious views, were foremost the friends and relations of Senopatty Ingalaga, whose minds were enflamed by the prediction that had been made to their ancestor Kiay Gedee Sisselo, Kiay Gede . . . and Kiay Gedee Mattaram concerning the future elevation of their descendents to the supreme authority of the Island Java, hoping each of them that some share of that greatness would devolve on him.--

None of all however showed himself more active and gallant than Tommogang Majang of Padjang brother in law to Senopatty Ingalaga which he carried to that excess so as to sacrifice his own son Radeen Panolan; knowing that his son was passionately fond of women, for which he himself several times had called him to account, and being equally well acquainted with the Jealous disposition of the Sultan, he encouraged the passion of the former for one of the concubines of the latter who had shown herself not indifferent to his advances.

The father, whilst he pointed out to his son the means to accomplish his desire warned the guard at the Seraglio to keep a good look out.

75De Graaf, Sénapati, p. 64. 
Radeen Panalan, who trusted to the advice given him by his father, braved all dangers to obtain his end, but he was seized in the Seraglio, brought before the Sultan who without farther inquiries ordered him to be kreessed and sent the corps to his father.--

The latter at the sight of his son's lifeless body showed signs of the utmost despair, not so much for the loss of his son, of which he himself was the cause, but for the ignominy that fell upon his family. He gave immediate notice of what had happened to his brother in law Senopatty Ingalaga and called upon him to take vengeance. Senopatty Ingalaga was a man of an irrasable temper, and considered the affront done to his brother in law as touching own honor, wherefore he lent a willing ear to the application of the latter.-On the feast of Moolot that year he neither made his appearance at Court nor sent his usual tribute, which surprised the sultan who sent the Tommongong Cliwongs Wiello Marto and Ragil to demand the cause of that neglect of duty and to make Senopatty Ingalaga sensible of it.--

Middelkoop is quite clear. The cause of Senapati's refusal to fulfill obligations to his overlord was his response to the insult to his brother-in-1aw, the outcome of a carefully designed plot by the latter to drive a wedge between Senapati and Sultan Pajang. In both the BTJ and the ESK, it is only after two embassies have already been sent to remonstrate with Senapati that the episode of Tummengung Mayang's son is introduced. In both of these versions Raden Pabelan is aided by his father in penetrating the women's quarter of the kraton for an assignation with a daughter (as opposed to concubine) of the Sultan. Tummengung Mayang is forced to flee to Mataram for his own safety (ESK) or banned to Semarang (BTJ). In neither case is there a suggestion that Mayang deliberately sacrificed his son in order to create bad blood between Senapati and Sultan Pajang. Raffles' quotation of Sultan Pajang's prophecy to his son, Prince Benawa (2, p. 444) is MMS, p. 153:

When the sultan heard this he called his son Radeen Benowa and said the will of Providence rules all the events of life. Senopatty Ingalaga shall not during my life time commence hostilities against me; but after my death he will render you subject to him. Yield to his power, of which your happiness and that of your family depends.which advice Radeen Benowa promised to follow.

Raffles' account of the Pajang expedition against Mataram, the defeat at Prambanan, and withdrawal of Pajang, is based on the MMS. The circumstances of the death of Sultan Pajang give us another occasion to comment on the differences between the tradition reported by Middelkoop and that contained in the ESK and BTJ.76 In the BTJ, Sultan Pajang is murdered by an invisible jinn servant of Senapati named Juru Taman. Juru Taman is spurred on by his master's ambiguous response to a suggestion that Pajang be assassinated. In the ESK we learn that the Sultan of Pajang became seriously ill and died a natural death. MMS takes the supernatural out of the BTJ story but at the same time denies Senapati's responsibility:

The young man Jokko Taman, who was with Senopatty Ingalaga, offered to him to get into the Dalm and to kill the Sultan, which

${ }^{76} \mathrm{Cf}$. ibid., pp. 87-88. 
Senopatty Ingalaga not only disapproved of, but became very angry and demonstrated against the cruelty and the inhumanity of his proposal. This however made but little impression upon the latter, who found means to become acquainted with the Sultans cooks, and having thus free admission to the cookroom, he one day mixed poison with the victuals prepared for the Prince which caused his Death within a few days aft $\mathrm{x}$.

Poison administered by an agent in the kraton seems a much more likely cause of death than an invisible jinn sitting on one's chest. Furthermore there is too much of a sense of proforma protest on Senapati's part to completely accept the MMS exculpation. This passage is an example of how the Middelkoop manuscript does have importance in furthering our knowledge of traditional Javanese history, complementing other sources in places and adding new "facts" in others. The ESK, 2, p. 39, gives the date of Pajang's death as 1526 A.J. or 208 years having elapsed before the present date 1807 A.D. [1599 A.D.j. De Graaf in his discussion of the death of Pajang sets it at 1587 A.D. primarily on the evidence of the "very reliable" Babad Sengkala.77 He does not mention that the ESK gives a much later date. No date for this event is given in the Middelkoop manuscript.

As told by Raffles (2, pp. 145-46). After the death of Adi Wijaya, Sultan Pajang, the crown passed to the adipati of Demak, not Pangeran Benawa. The latter called upon Senapati for assistance but at the moment of victory in the struggle against Demak, Bennawa retreated from the secular life to become a holyman. Senapati took possession of the Pajang regalia and assumed the title of Sultan of Mataram. This is drawn from MMS, pp. 159-62. The dream voice heard by Benawa on the eve of battle, quoted by Raffles, is identified in MMS, p. 460, as Pangeran Tumpait (Tembayat). This is not noted in the BTJ or ESK. Senapati's wars to make himself master of Java are detailed in RHJ, 2, pp. 147-48, drawn from MMS, pp. 163-75. The name given to his favorite general, Senapati Kadiri, is Senapati Balik in the MMS (Raffles calls him Balek), an alias not known to the ESK or BTJ. MMS, p. 171, gives the date 1539 A.J. for the construction of the new wall around the Mataram kraton under Senapati Balik's supervision. This date is obviously in error since it is after the death of senapati. Probably this is why i.t was not picked up in Raffles. The MMS gives a slightly different account of the battle between Mataram and the East Javanese at Utĕr than either the BTJ or the ESK. ${ }^{78}$ According to the BTJ, Senapati Kadiri divided his army into two columns, a northern one led by Pangeran Purbaya, the southern by himself. ESK, 2, pp. 99-110, also says the army consisted of two columns, one led by Purbaya, the other by Senapati Kadiri. MMS, pp. 172-73, says Senapati Balik (= Kadiri) split the army into three columns: a center led by himself, a right wing led by pangerans Purbaya and Jaga Raga, and a left wing led by the other sons of Senapati. It was the right wing that encountered the East Javanese forces at Utĕr and it was during the East Javanese retreat that the center column hit the enemy on the flank. This led to the fight to the death between Senapati Balik and Patih Prsagi.

The Middelkoop manuscript enlightens us as to the fate of Pragola, the adipati of Pati after his defeat at Senapati's hands by Prambanan.

77Ibid., p. 89. $\quad$ 78Ibid., pp. 121-23. 
According to the BTJ the Pati forces withdrew to the east but the pursuing troops of Mataram fell upon them again. Many of the defenders drowned in an overflowing river, but it was not known whether or not Pragola lived or died. In the ESK, 2, pp. 118-19, the river Dengkeng overflows drowning many of the retreating Pati forces. The fate of Pragola is unknown. MMS, pp. 474-75, leaves no doubt as to what happened to the Pati leader.

At this act [the wounding of the crown prince] the Sultan became very angry and ordered his whole army instantly to the attack. The battle was long and bloody, but the troops of Patty were totally defeated, and pursued as far as the River Dikkeng, being an arm of the great Souracarta river which takes its course behind Padjang into the Sookowaty Districts. Kiay Gedee Bergallo and a number of his people were drowned.

The ESK date for the death of Senapati, 1533 A.J. or 201 years having elapsed before the current date of 1807 A.D. [1606 A.D.], is five years later than the date found in other sources. De Graaf, in his discussion of the date of Senapati's death did not mention the ESK date. 79

The picture of Senapati that emerges from Middelkoop's account is much less flattering than either the BTJ or the ESK. In the Middelkoop manuscript Senapati is depicted an irrascible, sharp-tempered adventurer. His career as adipati of Mataram is described as one of "plunders and outrageous behavior" (MMS, p. 154). Another important characteristic of the MMS when compared to the BTJ or ESK is that it has been stripped of many of the mythological qualities that play such an important role in legitimatizing Senapati as the founder of the Mataram dynasty. For example, an important part of the story of Senapati's conquest of the Madiun kraton (ESK, 2, pp. 79-82; BTJ 108-9) is his possession of Rĕtna Jumilah, the daughter of Panĕmbahan Madiun. She was armed with the magical kris Gumarang. Senapati's eventual sexual conquest of her clearly identified him with other mythic heroes of Javanese legend and poetry--Sedana, Pañji, and other "Visnu" figures, for Retna Jumilah was Dewi Shri.8o It is probably for this reason, rather than just her noble descent, that the Javanese assign such great weight to this episode in Senapati's life. The mythic theme, however, is completely absent from Middelkoop's narration; simply a bare mention that Senapati married the daughter of Madiun.

From the death of Senapati to the end of the MMS in 1717 A.D. Middelkoop's materials become essentially a history of the graduai ascendency of the VOC on Java. Increasingly the chronological guide posts are those of either Dutch military expeditions or treaties with the indigenous courts. Its connections to Javanese historiography can no longer be demonstrated. Although the MMS is certainly much more detailed than the RHJ, a specific link between the two texts, at least from the history of Sultan Agung forward, is no longer evident. For the legendary history and early Mataram, however, it appears established that Brandes' question about the documentary sources of Raffles'

79 Ibid., pp. 129-30.

${ }^{\circ}$ Donald E. Weatherbee, "Aspects of Ancient Javanese Politics" (Ph.D. dissertation, Johns Hopkins University, 1968), pp. 464ff. 
"History" can be answered confidently by reference to Middelkoop's "Collection of Javanese Historical Materia1s." The MMS, even more so than Engelhard's kanda translation, is evidence of the debt that later students of Java, working from Raffles' base, owed to his unappreciated Dutch predecessors and unknowing co-authors. It also underlines

Mackenzie's own misperceptions about the novelty of his research when he noted that little indeed had been done in Java by Europears with regard to historical inquiry. 81

81Mackenzie, "General View." 
